\title{
Leksikografiese behoeftevervulling.
}

\author{
Rufus H. Gouws, Departement Afrikaans en Nederlands, \\ Universiteit van Stellenbosch, Suid-Afrika
}

Abstract: Meeting Lexicographic Needs. A multilingual and multicultural South Africa has its own lexicographic needs and the fulfilment of these needs demands thorough planning and the employment of a sound and effective organisational theory. This paper focuses on a few priorities to meet the South African lexicographic needs. The contents of a dictionary as well as the presentation of the information should be directed at a well-defined target user. Not only the linguistic needs of this target user but also his research skills should have an influence on the planning and compilation of any specific dictionary. Using a metalexicographic model this paper discusses different aspects of interest in determining priorities for the fulfilment of lexicographic needs. Lexicographers have to be familiar with components like dictionary use, dictionary criticism, the history of dictionaries and a general theory of lexicography. The importance of planning and a sound training is emphasised. Training should not only be aimed at lexicographers but also at dictionary users. It is easier to achieve the meeting of lexicographic needs in an environment where a well-established dictionary culture exists.

Keywords: DICTIONARY, DICTIONARY CRITICISM, DICTIONARY CULTURE, DICTIONARY TYPOLOGY, DICTIONARY USE, FULFILMENT OF NEEDS, GENERAL THEORY OF LEXICOGRAPHY, HISTORY OF DICTIONARIES, LEXICOGRAPHY, METALEXICOGRAPHY, USER-FRIENDLINESS

Opsomming: in Meertalige, multikulturele Suid-Afrika het eiesoortige leksikografiese behoeftes en die vervulling hiervan verg indringende beplanning asook die aanwending van 'n doeltreffende organisasieteorie. In hierdie artikel word aandag gegee aan enkele prioriteite vir die vervulling van die Suid-Afrikaanse leksikografiese behoeftes. Daar word van die standpunt uitgegaan dat die inhoud van 'n woordeboek sowel as die aanbieding van inligting gerig moet wees op 'n duidelik omskrewe teikengebruiker. Nie net die linguistiese behoeftes van hierdie gebruiker nie maar ook sy naslaanvaardighede speel 'n rol by die beplanning van 'n spesifieke woordeboek Aan die hand van 'n metaleksikografiese model word verskillende aspekte bespreek wat 'n invloed op die vasstelling van prioriteite in die vervulling van leksikografiese behoeftes kan hê. Leksikograwe en voornemende leksikograwe moet vertroud wees met woordeboekgebruik, woordeboekkritiek, die geskiedenis van woordeboeke sowel as 'n algemene leksikografieteorie. Die waarde van beplanning en opleiding word deurgaans sterk beklemtoon. Opleiding moet nie net op woordeboekopstellers gerig wees nie maar ook op woordeboekgebruikers. Leksikografiese behoeftevervulling word makliker bereik in 'n omgewing waar 'n woordeboekkultuur reeds gevestig is.

Hierdie referaat is gelewer by die seminaar leksikografie as 'n finansiële bate in 'n veeltalige Suid-Afrika, gehou by die Buro van die Woordeboek van die Afrikaanse Taal, Stellenbosch, 12 April 1996. 
Sleutelwoorde: ALGEMENE LEKSIKOGRAFIETEORIE, BEHOEFTEVERVULLING, GEBRUIKERSVRIENDELIKHEID, GESKIEDENIS VAN WOORDEBOEKE, LEKSIKOGRAFIE, METALEKSIKOGRAFIE, WOORDEBOEK, WOORDEBOEKGEBRUIK, WOORDEBOEKKRITIEK, WOORDEBOEKKULTUUR, WOORDEBOEKTIPOLOGIE

\section{Inleidend}

Die leksikografie het sy ontstaan in 'n preteoretiese omgewing gehad. Die samestelling van die eerste woordeboeke is nie aan die hand van teoretiese modelle uitgevoer nie maar is gedoen ter bevrediging van die praktiese behoeftes van werklike gebruikers. Een van die belangrikste kenmerke van die leksikografiese ontwikkeling van die afgelope twee dekades is 'n leksikografiese perspektiefverandering wat gelei het tot die vestiging van 'n sterk teoretiese komponent in die leksikografie en tot 'n aktiewe wisselwerking tussen teorie en praktyk. In hierdie "Goue Eeu van die leksikografie", vgl. Ilson (1985), is die tradisionele leksikografiese praktyk gehandhaaf maar daarnaas en aanvullend daartoe het die metaleksikografie sy plek as volwaardige dissipline ingeneem. 'n Ondersoek na in volgorde vir leksikografiese behoeftevervulling moet gevolglik aan sowel die teoretiese as die praktiese aspekte aandag gee.

Oor die status van die leksikografie is daar al baie en baie uiteenlopende uitsprake gemaak. Of die leksikografie as 'n wetenskap, 'n vaardigheid, 'n spesiale tegniek al dan as 'n kunsvorm beskou moet word, is vir baie mense geen onproblematiese besluit nie, vgl. Wiegand (1989: 246 e.v.). Vir Wiegand (1989: 248 ) is die leksikografie 'n wetenskaplike praktyk want die werklike leksikografiese bedrywighede is nie daarop gerig, soos in die geval van 'n wetenskap, om teorieë te formuleer of te toets nie, maar die een gemeenskaplike kenmerk van alle leksikografiese bedrywighede is hulle doelstelling dat woordeboeke as gebruiksvoorwerpe tot stand gebring moet word (Wiegand 1989: 251). Leksikografie is 'n praktyk wat daarop gerig is om woordeboeke tot stand te bring sodat 'n ander praktyk, naamlik die kulturele praktyk van woordeboekgebruik, moontlik gemaak kan word. Die suksesvolle uitvoering van die leksikografiese praktyk word medebepaal deur invloede uit die teoretiese taalkunde. Taalteorieë is nie spesifiek op die leksikografiese praktyk gerig nie en oor jare heen moes leksikograwe bestaande taalteorieë analiseer en interpreteer met die oog op die toepasbaarheid daarvan vir die leksikografie. Algaande het die behoefte ontstaan aan 'n algemene leksikografieteorie wat aan praktiserende leksikograwe die nodige teoretiese leiding kon bied.

Die werk wat oor veral die afgelope twee dekades in hierdie verband gedoen is, het gelei tot die ontwikkeling van die metaleksikografie as 'n volwaardige komponent binne die breër leksikografiese terrein. Volgens Wiegand (1984: 14 e.v.) moet 'n algemene leksikografiese teorie op 'n sistematiese manier 'n verwerking en verduideliking bied ter motivering van die kennis wat nodig is om leksikograwe toe te rus om hulle werk op ' $n$ gepaste manier en so goed as 
moontlik te doen. In die leksikografiese praktyk moet 'n onderskeid gemaak word tussen linguistiese en saakleksikografie. Tot die laasgenoemde kategorie behoort ensiklopedieë en vakwoordeboeke wat nie primêr gerig is op 'n weergawe van taalkundige inligting nie. Die eerste kategorie bevat gewone verklarende en vertalende asook ander woordeboeke wat die taalkundige bewerking van lemmas as hoofdoel het. Om verwarring te voorkom wanneer daar na die verskillende komponente van die leksikografie verwys word, maak Wiegand (1989: 253) 'n onderskeid tussen linguistiese leksikografie, dit is die praktiese komponent, en woordeboeknavorsing, dit is die teoretiese komponent. Hartmann (1996: 238) maak 'n onderskeid tussen woordeboek skryf en woordeboeknavorsing.

Bestaande metaleksikografiese modelle is primêr daarop gerig om 'n verhoging in die gehalte van woordeboeke tot gevolg te hê. Alhoewel woordeboekprojekte vandag nog soms met 'n redelike mate van sukses in 'n omgewing geisoleerd van teoretiese invloed tot stand kan kom, kan dit algemeen aanvaar word dat 'n deeglike teoretiese begronding een van die eerste prioriteite van enige leksikograaf of voornemende leksikograaf moet wees. Hier speel metaleksikografiese bevoegdheid 'n wesenlike rol. Om vertroud te raak met die eise van die metaleksikografie, kan as 'n eerste stap in die volgorde van leksikografiese behoeftevervulling gesien word.

\section{Die Suid-Afrikaanse leksikografiese toneel}

Die meertalige en multikulturele Suid-Afrikaanse samelewing bring 'n eiesoortige stel leksikografiese eise mee. Dié belangrikste aspek van toekomstige leksikografiese behoeftevervulling in die Suid-Afrikaanse konteks is deeglike beplanning en die inwerkingstelling van 'n sogenaamde organisasieteorie. Ongelukkig was dit tot dusver geen opvallende kenmerk van die meeste SuidAfrikaanse leksikografiese bedrywighede nie.

Die beplanning van leksikografiese projekte in 'n meertalige en multikulturele samelewing kan vanuit verskillende vertrekpunte gedoen word. 'n Panorganisatoriese benadering kyk oorkoepelend na die leksikografiese prentjie en doen voorstelle aan die hand. ' $n$ Taalspesifieke beriadering daarenteen vereis dat daar afsonderlike leksikografiese beplanning vir elke indiwiduele taal gedoen word. In die eerste geval sal algemene leksikografiese neigings die opdragte domineer terwyl taalspesifieke behoeftes in die laasgenoemde geval die sterkste aan die orde kom. Oorvleueling is 'n probleem wat baie maklik kan ontstaan in die geval van die taalspesifieke model. Die bergpredikasiesindroom, dit wil sê waar die linkerhand nie weet wat die regterhand doen nie, lei maklik daartoe dat taal $X$ byvoorbeeld besluit om ' $n$ vertalende woordeboek met die taalpaar $X$ en $Y$ te maak, terwyl taal $Y$ terselfdertyd ook op so 'n woordeboek besluit. Die geskeie werkswyses sou dan baie maklik leksikografiese teenproduktiwiteit in die hand kon werk. Daarom is dit belangrik dat die twee benaderings nie onderling uitsluitend moet wees nie. 
'n Onderskeid wat gemaak moet word, is dié tussen sake van algemene belang en sake wat slegs taalspesifieke waarde het. In die beplanning rondom sowel die linguistiese as die saakleksikografie in 'n meertalige bestel behoort die swaartepunt op die taalspesifieke benadering te wees, maar die indiwiduele tale mag nie slegs in isolasie werk nie. Ruimte moet geskep word vir beplanning van gemeenskaplike projekte. Uit die navorsing van Wiegand wat tot die formulering van sy metaleksikografiese beginsels gelei het, blyk die algemene en nie-taalspesifieke toepassingswaarde van sy teorie baie duidelik. Woordeboeknavorsing is nie gerig op die taalspesifieke nie maar stel die fokus op 'n algemene leksikografieteorie. Dit is geen geheim dat leksikograwe 'n baie klein deelversameling van die spesie homo sapiens uitmaak en dat die hoop op inflasie binne hierdie subkultuur gering is. Daarom is dit des te belangriker dat die praktiese leksikografie van indiwiduele tale wel deur kundiges en deskundiges uit die betrokke taalgemeenskappe bedryf moet word, maar dat navorsing en kundigheid oor gedeelde waardes nie by wyse van oorvleueling deur lede van elke gemeenskap gedoen moet word nie. Dit geld veral ook die SuidAfrikaanse leksikografiese toneel. Sentra moet bestaan waar taalspesifieke leksikografiese projekte uitgevoer word. Die praktiese werk wat in hierdie sentra gedoen word, moet steeds ' $n$ wisselwerking vertoon met die werk wat op die metaleksikografiese terrein gedoen word. Praktiserende leksikograwe se dagtaak maak dit vir hulle onmoontlik om volledig vertroud te bly met die heersende metaleksikografiese strominge. Elke projek moet egter blootgestel word aan bevindinge uit die metaleksikografiese navorsing wat vir die spesifieke projek van waarde is. Gevolglik is die bestaan van 'n sentrum of sentra van metaleksikografiese kundigheid en die toegang van indiwiduele woordeboekprojekte tot so 'n sentrum een van die werklike prioriteite in die proses van leksikografiese behoeftevervulling in Suid-Afrika.

\section{Tipologiese verskeidenheid versus gebruikersbehoeftes}

Die taalverskeidenheid en die behoefte aan verskillende woordeboeksoorte het reeds baie bygedra tot die omvang van Suid-Afrikaanse leksikografiese projekte. Daar is sekere wanbalanse tussen tale, tussen woordeboeksoorte en tussen bestaande leksikografiese werkswyses. Riglyne is nodig sodat die strewe na 'n bevredigende woordeboekversameling so gou en so goed as moontlik verwesenlik kan word. Om dit moontlik te maak, moet daar vir elke Suid-Afrikaanse taal ' $n$ indringende behoeftestudie gedoen word. Alhoewel so ' $n$ studie die behoeftes van die leksikografiepraktyk moet aandui, val dié studie onmiddellik binne die oorvleuelingsterrein van teorie en praktyk.

Die vasstelling van leksikografiese behoeftes mag nie gedoen word met ' $n$ berekening soos die volgende nie: 


\section{Dit is die volledige tipologiese verskeidenheid}

- Dit het ons

$=$ Dit het ons nodig.

Leksikografiese behoeftes is nie die verskil tussen die beskikbare woordeboeke van enige gegewe taal en dié van die volledige tipologiese spektrum nie. Die toepassing van so 'n benadering kan baie maklik lei tot 'n konflik tussen woordeboek en gebruiker omdat die gebruiker, ondanks die tipologiese uitgebreidheid van 'n gegewe taal se leksikografiese praktyk, nie 'n bevrediging van sy / haar werklike behoeftes vind nie. 'n Taal wat oor slegs enkele woordeboeke beskik, mag in 'n hoër mate die leksikografiese behoeftes van die spesifieke taalgemeenskap bevredig as wat die geval is met 'n taal wat oor 'n uitgebreide tipologiese verskeidenheid beskik. Leksikografiese behoeftevervulling mag nie primêr gerig wees op die produksie van woordeboeke ter vervollediging van die teikentaal se tipologiese spektrum nie; dit moet gerig wees op die produksie van woordeboeke ter bevrediging van die teikentaalgemeenskap se leksikografiese behoeftes. Dit mag byvoorbeeld meebring dat ' $n$ eerste prioriteit vir ' $n$ gegewe taal die produksie van 'n woordeboeksoort is wat reeds in die betrokke taal bestaan maar wat nie aan die nodige vereistes voldoen om die gebruikersbehoeftes te bevredig nie. Die produksie van enige nuwe woordeboek asook die heruitgawe van bestaande woordeboeke moet uit 'n gebruikersgedrewe behoefte volg. Die tyd is verby vir die publikasie van woordeboeke ter wille van woordeboeke.

Dit is nie om dowe neute dat Wiegand in sy raamwerk vir die metaleksikografie navorsing oor woordeboekgebruik tot een van die hoofkomponente verhef nie, vgl. die bespreking wat volg oor die hoofkomponente van 'n metaleksikografiese model. Hierdie komponent is juis daarop gerig om dinge vir die gebruiker makliker te maak in die benutting van woordeboeke en die ontsluiting van die verskillende inligtingstipes. Volgens Kühn (1989: 112) moet die gebruik van 'n woordeboek as 'n kommunikatiewe handeling begryp word. So 'n siening het regstreekse implikasies vir die leksikograaf. Die sentrale funksie van woordeboeke is dat hulle as naslaanwerke 'n kulturele praktyk bevorder, vgl. Reichmann (1988: 395). Dit is 'n kultuurpedagogiese rol waardeur sowel linguistiese as saakwoordeboeke die werk van die skool voortsit en uitbou, of dikwels selfs vervang; selfs al bereik hulle nie hulle doel ten volle nie. Wat van bepalende belang is, is dat die naslaanhandeling suksesvol uitgevoer moet word. Dit is slegs moontlik as die leksikografie en die teikengemeenskap in harmonie met mekaar verkeer, vgl. Hausmann (1989: 13). Hierdie harmonie word dikwels bedreig deurdat die hoë inligtingsdigtheid en die komplekse aanbiedingstruktuur van woordeboeke die gewone gebruiker van die woordeboek vervreem. In 'n gebruikersgedrewe leksikografie kan hierdie konfliksituasie ontlont word deur die vestiging van 'n benadering van gebruikersvriendelikheid en van 'n woordeboekkultuur. Volgens Hausmann (1989: 13) verwys gebruikersvriendelikheid in hierdie konteks na 'n aanpassing van die leksikografie by die gemeenskap, terwyl woordeboekkultuur te make het met die aan- 
passing van die gemeenskap by die leksikografie. Hierdie twee begrippe moet as swaartepunte binne 'n gebruikersgedrewe leksikografie beskou word. Dit plaas 'n verantwoordelikheid op sowel die leksikograaf as die gemeenskap.

Ter wille van gebruikersvriendelikheid moet die leksikograaf nie net vertroud wees met die spesifieke taalkundige behoeftes van 'n vooraf bepaalde teikengebruikersgroep nie maar hy / sy moet ook rekening hou met dié groep se naslaanvaardighede. Om die sukses van 'n woordeboek te verseker, moet die leksikograaf die inligting op so 'n manier aanbied dat die verlangde inligtingsoordrag so maklik as moontlik kan plaasvind en dat die teikengebruiker maklike toegang tot die verstrekte inligting het.

Die basis van enige gesprek oor leksikografiese behoeftevervulling mag nie fokus op 'n standpuntinname oor die produksie van woordeboeke nie. Die vertrekpunt van so 'n gesprek moet binne 'n metaleksikografiese raamwerk wees. Dit gaan nóg oor tipologiese uitbreiding nóg oor 'n uitbouing van óf die makro- óf die mikrostruktuur van bestaande woordeboeke. Die vasstelling van leksikografiese behoeftes sowel as van 'n volgorde vir die vervulling daarvan moet volgens ' $n$ gebruikersgedrewe model gedoen word en wel aan die hand van objektiewe kriteria wat volg uit primêre woordeboeknavorsing.

As daar vir die Suid-Afrikaanse situasie gekyk moet word na 'n volgorde van leksikografiese behoeftevervulling, is dit belangrik om aandag te gee aan sowel taalspesifieke as algemene aspekte. Riglyne hiervoor word vervolgens gebied.

\section{Taalspesifieke aspekte}

Alhoewel dit belangrik is dat daar vir elke Suid-Afrikaanse taal 'n behoorlike opname gemaak moet word van beskikbare woordeboeke, vergelyk in hierdie verband die werk wat reeds gedoen is in Alberts en Mtintsilana (1988), moet Hartmann (1989: 103) se uitspraak in gedagte gehou word, naamlik dat die ontwerp van enige woordeboek voorafgegaan moet word deur 'n analise van gebruikersbehoeftes. Dit geld nie net die ontwerp van die enkele woordeboek nie maar ook die beplanning van enige breër leksikografiese netwerk. 'n Wesenlike vertrekpunt in die vasstelling van 'n volgorde van leksikografiese behoeftevervulling vir die Suid-Afrikaanse tale is dat daar vir elkeen van dié tale indringend aandag gegee moet word aan 'n empiriese ondersoek na die werklike leksikografiese behoeftes van die betrokke taalgemeenskap. Omdat hierdie ondersoek ten beste binne 'n teoretiese raamwerk kan geskied, is dit belangrik dat beplanners vertroud moet wees met die heersende strominge in die metaleksikografie. Vir hierdie doel is dit nodig dat aandag gegee moet word aan die kriteria wat gestel word in 'n: algemene leksikografieteorie. In hierdie verband bied die teoretiese werk van H.E. Wiegand nuttige leiding aangesien die formulering van 'n algemene leksikografieteorie een van die hoofkomponente van sy metaleksikografiese beskouing is. 


\section{1 'n Metaleksikografiese raamwerk}

In 'n gesprek oor die metaleksikografie moet daar geen twyfel bestaan oor die status en funksie van die teoretiese riglyne wat deur die metaleksikografiese raamwerk aan die praktiserende leksikograaf voorgeskryf word nie. Volgens Geeraerts (1989: 287) is die beginsels van leksikografie eerder vergelykbaar met dié van die ingenieurswese as met dié van die wette van die fisika. Die wette van die fisika spesifiseer die beginsels wat die struktuur en optrede van die fisiese werklikheid beheer. Die beginsels van die leksikografie is egter nie taalwette nie. Hulle spesifiseer nie die fundamentele reëls wat die linguistiese struktuur en linguistiese optrede beheer nie. Hulle spesifiseer die onderliggende aksiomas van sekondêre strukture en sekondêre optrede. Die struktuur van woordeboeke en die optrede van leksikograwe is slegs indirek verwant aan die struktuur van taal en die optrede van taalgebruikers; soortgelyk aan die manier waarop die beginsels van ingenieurswese verwant is aan die reëls van die fisika. Ingenieurswese is 'n doelgerigte menslike aktiwiteit wat aandag moet gee aan onder andere die wette van die materiële wêreld. Net so is leksikografie ' $n$ doelgerigte menslike aktiwiteit waarvoor die beginsels van taal een van $n$ reeks parameters is wat die uiteindelike vorm van 'n woordeboek bepaal.

Wiegand (1984: 14 e.v.) onderskei vier hoofafdelings waaruit die metaleksikografie bestaan, te wete navorsing oor woordeboekgebruik, navorsing oor die geskiedenis van leksikografie, navorsing oor woordeboekkritiek en navorsing oor ' $n$ algemene leksikografieteorie. Onder 'n algemene leksikografieteorie sluit Wiegand aspekte in soos die volgende: die doel van 'n woordeboek, orgarisasieteorie en die beplanning van woordeboekprojekte, leksikografiese taalnavorsing wat fokus op die verkryging, toetsing en verwerking van data, asook leksikografiese taalbeskrywing wat woordeboektipologie en die teksteorie vir leksikografiese tekste aan die orde stel. Behoeftebepaling en die volgorde vir die vervulling van leksikografiese behoeftes van indiwiduele tale kan met sukses binne hierdie raamwerk van Wiegand gedoen word.

\subsubsection{Navorsing oor woordeboekgebruik}

Oor hierdie aspek van die metaleksikografie word daar nie nou volledig gepraat nie. Vir enige leksikografiese projek maar ook vir die breër leksikografiese bedryf van enige indiwiduele taal moet navorsing oor woordeboekgebruik as een van die belangrikste vertrekpunte dien. Dit is veral die posisie van die gebruiker, sy behoeftes en sy vaardighede wat hier ter sprake kom. Vergelyk Hartmann (1996: 242 e.v.) se siening dat die beslissende rede vir die bestaan van woordeboeke, die behoefte aan inligting is. Die lokus van hierdie naslaanbehoeftes is die woordeboekgebruiker met sy bevoegdhede en vooroordele. Dit moet nie nodig wees om te raai waarvoor ' $n$ bepaalde werk deur ' $n$ 
anonieme koper gebruik moet kan word nie. Daar moet empiries vasgestel word vir watter funksies dit saamgestel is om óf ' $n$ voordelige of ' $n$ onbevredigende gebruik te hê. Verskillende metodes kan gevolg word om hierdie vasstelling suksesvol af te handel.

Die manier waarop woordeboekontsluitingsvaardighede aangeleer moet word, staan sentraal in die navorsing oor woordeboekgebruik. Vir die SuidAfrikaanse situasie is dit van die hoogste belang.

\subsubsection{Navorsing oor die geskiedenis van woordeboeke}

Die meeste woordeboeke het voorgangers en ook navolgers, vgl. Hartmann (1986: vii). Daarom is 'n goeie begrip van die oorsprong en ontwikkeling van woordeboeke belangrik vir die vooruitgang van die leksikografie. Dit moet aanvaar word dat min woordeboeke sonder enige steun op vroeëre woordeboeke tot stand kom. As dit binne perke gedoen word, is daar in beginsel geen fout hiermee te vind nie. Waarmee daar wel fout te vind is, is wanneer woordeboekgebruikers mislei word deurdat hulle onder ' $n$ verkeerde indruk gebring is aangaande die aard, omvang, selfstandigheid en funksies van 'n spesifieke woordeboek. Hierdie soort woordeboekkriminaliteit, vgl. Hausmann (1989: 99), is dikwels daaraan te wyte dat leksikograwe nie erkenning aan hulle bronne of 'n duidelike uitspraak oor die spesifieke woordeboeke maak nie.

In die vasstelling van 'n volgorde vir leksikografiese behoeftevervulling in Suid-Afrika moet daar aandag gegee word aan die invloed wat bestaande woordeboeke steeds op nuwe woordeboekprojekte uitoefen. Dolezal (1986: 47, 54) wys daarop dat die geskiedenis van die Engelse leksikografie bewys dat die "Engelse woordeboek" gesien kan word as 'n enkele bewerkte en herbewerkte teks. In die Suid-Afrikaanse leksikografie het sekere woordeboeke en woordeboeksoorte, en by name die vertalende woordeboeke met Afrikaans en Engels as taalpaar, ' $n$ dominante invloed gehad. Vergelyk in hierdie verband Gouws (1986), (1989), (1990) en Gouws en Ponelis (1992). Hierdie invloed het uitgegaan van 'n taalpaar waarvan albei die lede die enigste twee amptelike tale van die land was. Die amptelike status van hierdie tale het noodwendig daartoe gelei dat hulle oor die algemeen beter beheers is as ander nie-amptelike tale. Die hoë inligtingsdigtheid van hierdie woordeboeke het regstreeks verband gehou met die veronderstelde vertroudheid van die teikengebruikers met albei die behandelde tale. Sulke woordeboeke was dikwels uiters ontoeganklik vir die vermeende teikengebruiker. Dit was dié gevolg van 'n foutiewe siening van die gebruiker se behoeftes en naslaanbevoegdhede. Navorsing oor die geskiedenis van woordeboeke is nodig om die voortsetting van hierdie praktyk te voorkom en om te sorg dat sulke woordeboeke nie as rolmodelle vir ander vertalende woordeboeke dien nie; veral waar die teikengebruikers ' $n$ mindere vertroudheid met albei die behandelde tale het.

Ook in die verklarende leksikografie moet rolmodelle met omsigtigheid 
gekies word. Die oorheersende rol wat Engels tans in Suid-Afrika speel, mag nie daartoe lei dat Britse en Amerikaanse Engelse verklarende woordeboeke sonder meer as voorbeeld van gangbare leksikografie vir die Suid-Afrikaanse tale gesien word nie. Die eie aard van die teikengebruikers van Suid-Afrikaanse woordeboeke se leksikografiese behoeftes moet lei tot 'n vasstelling van die spesifieke tipologiese kategorie maar ook tot die vasstelling van die tersaaklike mikrostrukturele bewerking wat in plaaslike woordeboeke aangebied moet word.

Van die uiterste belang vir die Suid-Afrikaanse tale is dat alle gevestigde en voornemende leksikograwe nogmaals vanuit 'n historiese perspektief moet kyk na die ontwikkeling van ' $n$ ' spesifieke taal se leksikografiepraktyk. Uit hierdie oorsig moet ' $n$ herwaardering van bestaande projekte volg en ' $n$ vasstelling van tipologiese, subtipologiese maar ook aanbiedings- en inligtingsbehoeftes. Dit is ' $n$ voorvereiste vir die sinvolle voortgang van enige taal se leksikografiese praktyk.

\subsubsection{Woordeboekkritiek}

Navorsing oor woordeboekkritiek word met reg binne die Wiegand-model as 'n terrein van die metaleksikografie gesien. Woordeboekkritiek is een van die min vorme van inspraak wat linguis, metaleksikograaf en algemene woordeboekgebruiker in die leksikografiepraktyk het. Naas uitsprake oor die teoretiese en linguistiese gehalte van 'n woordeboek is dit juis ook gebruiksaspekte en die mate waarin die woordeboek teikengebruiker- en behoeftegerig is wat in woordeboekkritiek aan die orde kom. Nie net moet die leksikograaf of redaksie van 'n enkele woordeboek hulle by die herbewerking van die teks aan die kritiek op voorafgaande dele steur nie, maar leksikografiese beplanners moet die volgorde van 'n spesifieke taal se leksikografiese behoeftevervulling vasstel met inagneming van die uitsprake wat in die woordeboekkritiek na vore gekom het.

Hier kan twee voorbeelde genoem word waar woordeboekkritiek 'n regstreekse invloed op die leksikografiese praktyk gehad het. Die geskiedenis van die WAT bevat talle voorbeelde van ernstige kritiek op sowel die werkswyse as die inhoud van hierdie woordeboek. Kritici het hulle, soms ten regte maar ook soms ten onregte, veral sterk uitgespreek teen die aanbod in dele VI en VII. In deel VIII se toeligting word verwys na 'n deeglike strategiese beplanning wat vir die Buro van die WAT gedoen is en wat tot gevolg gehad het dat die redaksionele stelsel ingrypend hersien is. Dit word genoem dat die stelsel aangepas is by die hedendaagse stand van die taalkunde en die leksikografie en dat daar in die verfyning van die stelsel sover moontlik uitvoering gegee is aan die kommentaar en voorstelle deur resensente van deel VII. In die inleiding van deel IX word ook na die strategiese beplanning verwys en die feit dat verskeie eksterne kundiges betrek is by dié hersiening van die redaksionele stelsel. 

$\mathrm{afi}^{\mathrm{e}^{5}}$ werk wat tot nog toe deur die Buro voortgebring is. Aandag aan die WAT gelei. Dassing daarvan lei tot 'n hoër graad van leksikografiese behoefteverven $d^{j} e^{t}$ by hulle teikengebruikers.

$j^{1{ }^{1}}$ in die internasionale leksikografiese ontwikkeling het die spesifieke $\mathrm{n}^{\mathrm{f}^{\mathrm{ft}} \mathrm{es}}$ van die taalaanleerder gelei tot 'n tipologiese uitbreiding wat tot die

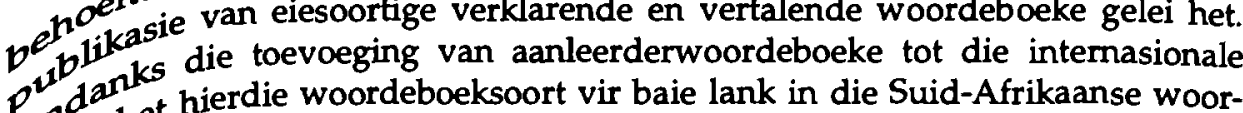
$\mathrm{O}^{1} \mathrm{k}^{\mathrm{h}}$ het hierdie woordeboeksoort vir baie lank in die Suid-Afrikaanse woor-

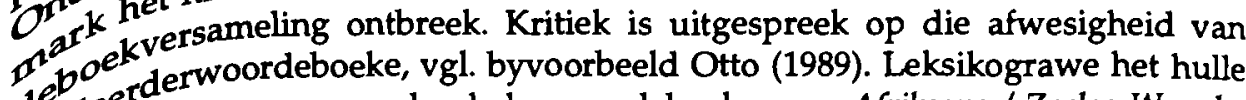
a $a^{y^{2}} a^{n}$ gesteur en vandag help woordeboeke soos Afrikaans / Zoeloe Woorde$d_{2}^{2}{ }^{k}$ Tweetalige Aanleerderswoordeboek / Bilingual Learner's Dictionary en Basisfor deboek van Afrikaans met die vervulling van die taalaanleerder se leksiko$v^{0} \mathrm{fi}^{\mathrm{C}^{\mathrm{e}}}$ behoeftes.

1.4

in Algemene leksikografieteorie

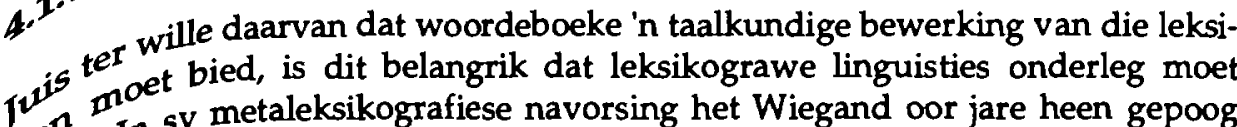
$10^{\mathcal{O}^{\mathfrak{h}}}$. In sy metaleksikografiese navorsing het Wiegand oor jare heen gepoog 的 raamwerk te ontwikkel wat as riglyn vir leksikograwe kan dien in die $\mathcal{O}^{\prime} \mathfrak{b}^{i} e^{\text {ding }}$ van 'n algemene leksikografieteorie was die probleem van vir die

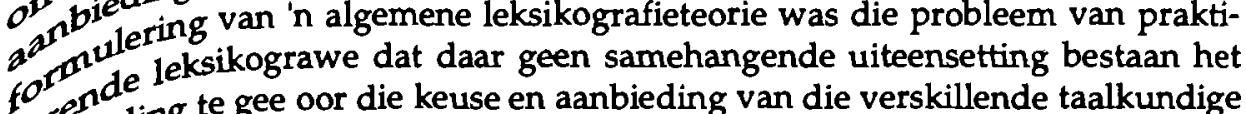
$s^{\mathfrak{f}^{\mathfrak{e}}} \mathfrak{l}^{\mathrm{i}}$ ding te gee oor die keuse en aanbieding van die verskillende taalkundige

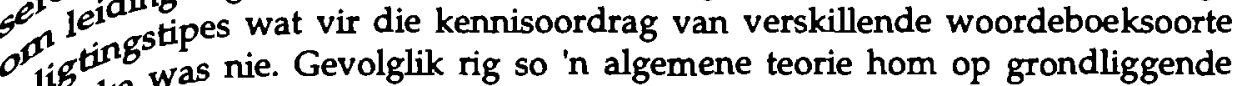
$\mathfrak{i n} \mathrm{gake}^{\mathrm{k}}$ was nie. Gevolglik rig so 'n algemene teorie hom op grondliggende $e^{r} e^{k t e}$ soos die doel van 'n woordeboek, organisasieteorie en die beplanning

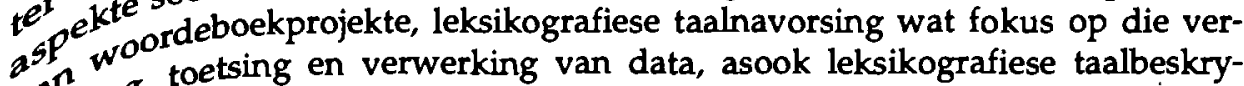
$a^{\mathfrak{H}^{\mathrm{h}}} \mathrm{w}$, toetsing en verwerking van data, asook leksikografiese taalbeskry$10 f^{g}$ wat woordeboektipologie en die teksteorie vir leksikografiese tekste

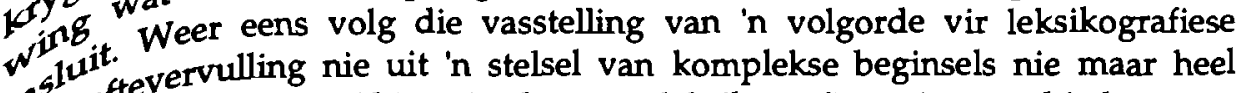
$\mathfrak{j}_{\mathrm{n}} \mathrm{oe}^{\mathrm{fte}}$ ervulling nie uit 'n stelsel van komplekse beginsels nie maar heel $b^{2} \mathrm{kti}^{\mathrm{ti}} \mathrm{se}^{\mathrm{e}}$ riglyne word binne 'n algemene leksikografieteorie aangebied. $p^{f^{2}}$ Binne die Suid-Afrikaanse leksikografiese praktyk kan suksesvolle ' $n$ van die leksikon verslag moet doen, moet ' $n$ geldige en verteenwoordi$\mathfrak{b}^{\mathcal{O}^{\mathfrak{K}}}$ de versameling leksikonitems opgeneem en bewerk word. Die korrekte $G_{\mathfrak{H}^{2}} \mathrm{ni}^{\mathrm{er}}$ van dataversameling asook taalkundig aanvaarbare bewerkingsmeto- 
des kenmerk goeie leksikografiese produkte. Die korrekte hantering hiervan moet as voorvereistes vir sukses in enige leksikografiese bedryf gesien word.

\section{Algemene navorsing, beplanning en leiding}

Dit is belarigrik dat leksikografiese beplanning vir elke taal en taalgemeenskap gedoen moet word. Hierdie beplanning moet nie van buite af op 'n spesifieke taal se leksikograwe afgedwing word nie, maar moet, met inagneming van die eiesoortige behoeftes van die spesifieke taal, deur linguiste en leksikograwe van en vir die spesifieke taalgemeenskap gedoen word. Die ideaal is dat elke taal oor 'n leksikografiese infrastruktuur sal beskik wat voorsiening maak vir genoeg praktiese leksikograwe maar ook vir diegene wat op metaleksikografiese vlak met navorsing en beplanning kan help. Die werklikheid van die Suid-Afrikaanse situasie dwing 'n mens egter al gou om na ander moontlikhede te kyk.

Die huidige stand van die Suid-Afrikaanse leksikografie maak dit onmoontlik om van praktiserende leksikograwe te verwag om volledig vertroud te bly met die vinnig ontwikkelende metaleksikografie. Alhoewel leksikograwe alles in hulle vermoë doen om ruimte te laat vir metaleksikografiese invloed op hulle werk, verhinder die omvang van hulle werkslas hulle meestal om op die hoogte van die jongste ontwikkelinge te bly. Dit is vir baie lank ook vererger deur die afwesigheid van 'n samehangende leksikografieteorie. As tussenganger tussen die teoretiese taalkunde en die woordeboekgebruiker was die leksikograaf in die onbenydenswaardige posisie dat hy / sy uit 'n magdom gegewens in die teoretiese taalkunde self moes besluit wat vir 'n spesifieke woordeboek se taalkundige aard en inligtingsoordrag ter sake is. Nie net moes die leksikograaf die keuse maak nie maar die toepassing daarvan het ook sy / haar verantwoordelikheid geword.

Die verskyning van 'n omvattende werk soos Wörterbücher Dictionaries Dictionnaires. An International Encyclopedia of Lexicography (Hausmann et al. 1989-1991), aangevul deur boeke wat in die reeks Lexicographica Series Maior verskyn asook artikels in toonaangewende tydskrifte soos Dictionaries, International Joumal of Lexicography, Lexicographica en Lexikos het dit vir leksikograwe makliker gemaak om vinniger toegang tot onlangse metaleksikografiese bevindinge te kry. Enige praktiserende leksikograaf behoort dit as ' $n$ belangrike prioriteit in diens van sy / haar eie woordeboekprojek te sien om kennis te neem van hierdie publikasies en self by te dra tot die uitbouing van sy / haar metaleksikografiese kundigheid. Maar steeds moet hulp van 'n algemener aard as 'n wesenlike aanvulling tot dié selfonderrig gesien word.

In hierdie verband is die leksikografiekursusse wat aan verskeie SuidAfrikaanse universiteite aangebied word ' $n$ tree in die regte rigting. Vir die meeste praktiserende leksikograwe is toegang tot hierdie kursusse nie prakties haalbaar nie. Opleidingskursusse soos dié wat deur die Buro van die WAT aan- 
gebied word, is gevolglik van onskatbare waarde.

Opleiding kan as dié fondament vir die vervulling van Suid-Afrikaanse leksikografiese behoeftes gesien word. Hierdie opleiding moet egter deur navorsing ondersteun word en die bestek van die opleiding moet sodanig wees dat dit ' $n$ wye verskeidenheid rolspelers betrek. Die dae is verby dat net die leksikograaf opgelei moet word. Om 'n woordeboekkultuur in Suid-Afrika geskep te kry, is dit noodsaaklik dat die gemeenskap voorberei moet word om woordeboeke reg te kan gebruik. Dit bring mee dat onderwysers en onderwysbeplanners oortuig moet word van die waarde wat 'n komponent oor woordeboekgebruik in enige taalleerplan het. Skoliere en studente moet in woordeboekgebruik onderrig word. Hierdie opleiding moet egter ook uitgebrei word na diegene wat nie meer met skool, kollege of universiteit in aanraking is nie maar steeds op woordeboeke moet steun vir die bereiking van kommunikatiewe sukses in hulle daaglikse taalhandelinge. Om woordeboekgebruik aan sulke mense bekend te stel, moet nieregeringsorganisasies betrek word om as deel van gemeenskapsprojekte pasgeletterdes maar ook ander volwassenes in te lei in die woordeboekkultuur. Woordeboeke word wel deur leksikograwe saamgestel maar hulle word deur uitgewers gepubliseer. Ook hier is uitgebreide leksikografiese kennis noodsaaklik. Uitgewers moet met praktiserende en teoretiese leksikograwe saamwerk in die beplanning en herbeplanning van leksikografiese projekte.

Met inagneming van die groot behoefte aan opleiding in die breë SuidAfrikaanse leksikografiese wêreld is PROLEKS, die Program vir Leksikografie, in die Departement Afrikaans en Nederlands van die Universiteit van Stellenbosch tot stand gebring. PROLEKS het leksikografiese navorsing en opleiding as sy belangrikste teikengebiede en wil juis probeer om op hierdie manier 'n rol te speel in die Suid-Afrikaanse leksikografiese behoeftevervulling. PROLEKS is nie ' $n$ taalspesifieke projek nie en poog om al die leksikografiese rolspelers by sy opleidingswerksaamhede te betrek.

\section{Ten slotte}

Die bewerkstelliging van 'n voortdurende en produktiewe wisselwerking tussen leksikografiepraktyk en leksikografieteorie moet die basis vorm van leksikografiese behoeftevervulling in Suid-Afrika. Die wete aan die kant van die leksikograaf dat 'n woordeboek 'n praktiese gebruiksinstrument in die hande van 'n spesifieke teikengebruiker is met baie spesifieke behoeftes en vasstelbare naslaanvaardighede moet ' $n$ beslissende invloed hê op sowel die inhoud as die aanbieding van woordeboeke. Metaleksikografiese navorsing wat onder meer lei tot die voortgesette opleiding van leksikograwe en woordeboekgebruikers lei nie net tot gebruikersvriendelike woordeboeke nie maar ook tot die skep van 'n woordeboekkultuur. Dit is die belangrikste sleutel tot die vervulling van leksikografiese behoeftes in Suid-Afrika. 


\section{Bibliografie}

Alberts, M. en P. Mtintsilana. 1988. Leksikografiese ontleding van Afrikaanse en Afrika-tale leksikons. Pretoria: Raad vir Geesteswetenskaplike Navorsing.

Dolezal, F. 1986. How Abstract is the English Dictionary? Hartmann, R.R.K. (red.) 1986a:47-56.

Du Plessis, M. 1993. Tweetalige Aanleerderswoordeboek. Bilingual Leamer's Dictionary. Kaapstad: Tafelberg.

Geeraerts, D. 1989. Principles of Monolingual Lexicography. Hausmann, F.J. et al. (Reds.). 19891991: 287-296.

Gouws, R.H. 1986. Afrikaans Lexicography. Hartmann, R.R.K. (Red.). 1986a: 75-83.

Gouws, R.H. 1989. Leksikografie. Kaapstad: Academica.

Gouws, R.H. 1990. Information Categories in Dictionaries, with Special Reference to Southem Africa. Hartmann, R.R.K. (Red.). 1990: 52-65.

Gouws, R.H. en F.A. Ponelis. 1992. The Development of Afrikaans and the Lexicographical Tradition. Zgusta, L. (Red.). 1992: 77-104.

Gouws, R., I. Feinauer en F. Ponelis. 1994. Basiswoordeboek van Afrikaans. Pretoria: J.L. van Schaik.

Harras, G. (Red.). 1988. Das Wörterbuch: Artikel und Verweisstrukturen. Jahrbuch 1987 des Instituts für deutsche Sprache. Düsseldorf: 394-408.

Hartmann, R.R.K. (Red.). 1984. LEXeter '83 Proceedings. Tübingen: Max Niemeyer.

Hartmann, R.R.K. 1986. Preface. Hartmann, R.R.K. (Red.). 1986a: vii-viii.

Hartmann, R.R.K. (Red.). 1986a. The History of Lexicography. Amsterdam: John Benjamins.

Hartmann, R.R.K. 1989. Sociology of the Dictionary User: Hypotheses and Empirical Studies. Hausmann, F.J. et al. (Reds.). 1989-1991: 103-111.

Hartmann, R.R.K. (Red.). 1990. Lexicography in Africa. Exeter: University of Exeter Press.

Hartmann, R.R.K. 1996. Lexicography as an Applied Linguistic Discipline. Hartmann, R.R.K. (Red.). 1996a: 230-244.

Hartmann, R.R.K. (Red.). 1996a. Solving Language Problems. Exeter: University of Exeter Press.

Hausmann, F.J. 1989. Die gesellschaftlichen Aufgaben der Lexikographie in Geschichte und Gegenwart. Hausmann, F.J. et al. (Reds.). 1989-1991: 1-19.

Hausmann, F.J. et al. (Reds.). 1989-1991. Wörterbücher. Dictionaries. Dictionnaires. An International Encyclopedia of Lexicography. Berlyn: W. de Gruyter.

Ilson, R. (Red.). 1985. Dictionaries, Lexicography and Language Learning. Oxford: Pergamon Press.

Kotze, E. en P. Wela. 1991. Afrikaans / Zoeloe-Woordeboek. Kaapstad: Tafelberg.

Kühn, P. 1989. Typologie der Wörterbücher nach Benutzungsmöglichkeiten. Hausmann, F.J. et al. (Reds.). 1989-1991: 111-127

Otto, A.N. 1989. Kriteria vir 'n Afrikaanse aanleerderwoordeboek. Ongepubliseerde D.Litt-proefskrif. Universiteit van Stellenbosch.

Reichmann, O. 1988. Resümee der Tagung. Harras, G. (Red.), 1988: 394-408.

Wiegand, H.E. 1984. On the Structure and Contents of a General Theory of Lexicography. Hartmann, R.R.K. (Red.). 1984: 13-30.

Wiegand, H.E. 1989. Der gegenwärtige Status der Lexikographie und ihr Verhältnis zu anderen Disziplinen. Hausmann, F.J. et al. (Reds.). 1989-1991: 246-280.

Zgusta, L. (Red.). 1992. History, Languages, and Lexicographers. Tübingen: Max Niemeyer. 